\title{
The Effectiveness of Geogebra's Metacognitive Guidance to develop Critical thinking skills
}

\author{
Heris Hendriana, Wahyu Setiawan, Usman Aripin \\ IKIP Siliwangi, Jl. Terusan Jenderal Sudirman, Cimahi, Jawa Barat, Indonesia \\ e-mail: herishen@ikipsiliwangi.ac.id
}

\begin{abstract}
This research is a quasi-experimental study aiming at analyzing the role of the metacognitive guidance approach in order to improve high-school students' critical thinking skills by applying Non-Equivalent Control Group Design. This study involved high school students in one of the high schools in the city of Cimahi. In this study, the pretest for mathematical critical thinking skills is administered to two classes of students of control and experiment groups. The experimental group uses the metacognitive guidance approach assisted by GeoGebra software, whereas the control group uses the conventional method. Both classes receive the same hours of study, mathematics teacher as well as mathematics contents. The researcher conducted observations only in the experimental class. At the end of the treatment, a post-test for the two groups was carried out regarding students' mathematical critical thinking skills included processing the results of the test, namely the data. After this research has been carried out, the next step is to analyze the data and draw conclusions of the research. In analyzing the data, it is categorized into three levels, namely high, medium and low abilities. The data is analyzed by means of $t$-test to test the difference of two means of students' critical thinking ability. Data analysis was performed using the SPSS software. The analysis shows that there is a significant difference in mathematics critical thinking ability between the two groups of students.
\end{abstract}

Keywords: Critical thinking skills, Geogebra's Metacognitive Guidance

How to Cite: Hendriana, H., Setiawan, W., Aripin, U. (2019). The Effectiveness of Geogebra's Metacognitive Guidance to develop Critical thinking skills. International Journal on Emerging Mathematics Education, 3(2), 129-138. http://dx.doi.org/10.12928/ijeme.v3i2.13806

\section{INTRODUCTION}

Mathematics is one of the most important subjects to be mastered because almost every level of mathematics education is studied. Besides mathematics is closely related to daily life according to their respective capacities, such as traders who use their arithmetic abilities, architects with their measurements, astronomy with their predictions, etc. Like using percent, many people use percent in many jobs and activities in their daily lives (Aripin, Setiawan \& Hendriana, 2019; Hidayat \& Aripin, 2019; Putri \& Zulkardi, 2019).

Mathematical critical thinking is the basis of the process of thinking to analyze arguments and bring ideas to each meaning to develop logical thinking patterns. It was also expressed by (Marlina \& Harahap, 2018) that mathematical critical thinking is a process that leads to drawing conclusions about what we have to believe and actions to be taken. According to (Sari, Eriani, Audina, \& Setiawan, 2019), mathematical critical thinking is an activity of thinking about ideas or ideas related to a given concept or problem. Meanwhile, according to Ennis (Senjayawati, 2018) mathematical critical thinking is a process of thinking with the aim of making sensible decisions about what is believed to be truth can be done correctly. From some of the expert 
opinions above, it can be concluded that the ability to think critically mathematically is an effective thinking skill that can help someone to make, evaluate, and make decisions about what is believed or done. The indicators of Mathematical Critical Thinking Ability (KBKM) used in this study include the ability to analyze and evaluate arguments and evidence, prepare clarifications, arrange explanations based on relevant and irrelevant data, identify and evaluate assumptions. KBKM is very important for students because with these skills students are able to be rational and choose the best alternative choices for themselves. In addition, it is necessary to instill habits of mathematical critical thinking for students so that they can examine various problems that occur in everyday life (Nuryanti, Zubaidah, \& Diantoro, 2018)(Nugraha, 2018). This is in line with expert opinion that the ability to think critically mathematics is included in the teaching objectives of mathematics such as a) To have the ability to think logically, critically, creatively, innovatively, and independently learn, and to demonstrate critical, creative, accurate, objective, open thinking, selfconfidence, curiosity, interest, perseverance, perseverance; b) To appreciate the beauty and use of mathematics in everyday life (Nugraha, 2018)

But in reality, based on the preliminary analysis carried out in high school before the implementation of this study it was found that the average KBKM of high school students is still low. Likewise, Setiawan and Sari (2018) show that the average KBKM of high school students is still low, the average KBKM score of high school students is only 30 if, on a scale of $0-100$, this score is included in the low category. In addition, from the initial research by giving a KBKM test conducted by researchers in one of the high schools in Cimahi City, out of 36 students only 5 people were able to answer the questions correctly but were incomplete, while others only guessed the answers. Based on this, it can be concluded that the KBKM of high school students is relatively low. This can be seen from several studies and research results that have been carried out, including the results of the PPPPTK study which states that Indonesia's rank in the 2009 PISA (Program for International Students Assessment) which is held every 3 (three) years states that the ability in Indonesian mathematics shows a score that is below the OECD average and occupies the 61st position of 65 countries (Hendroanto et al., 2018). Whereas mathematical problems in PISA measure more reasoning ability, problem-solving, arguing, communicating, and thinking at a higher level than questions that measure standard technical abilities related to memory and calculation alone (Nuryanti et al., 2018)

Critical thinking requires effort, a sense of care about accuracy, willingness, and an attitude of not giving up easily when facing a difficult task. Likewise, from those who think critically, an open attitude towards new ideas is needed. Indeed this is not something easy, but it must and still be implemented in an effort to develop thinking skills (Ahmatika, n.d.)

In fact, the teaching and learning process generally does not encourage the achievement of critical thinking skills. There are two factors that cause critical thinking not to develop during education. First, the curriculum is generally designed with broad material targets so that teachers are more focused on completing the material. That is, completeness of the material is prioritized over students' understanding of mathematical concepts. Second, that learning activities in the classroom that have been carried out by the teacher are nothing but the delivery of information (lecture method), by activating the teacher more, while students are passive listening and copying, where the teacher occasionally asks questions and occasionally students answer. Then the teacher gives examples of questions, followed

IJEME, Vol. 3, No. 2, September 2019, 129-138. 
by giving exercises that are routine and lack of training in critical power; finally, the teacher gives an assessment.

To anticipate these problems, it is necessary to find an alternative method of learning that is appropriate so that it can improve students' critical thinking skills. Teachers should continue to try to arrange and apply various ways that are varied so that students are interested and excited in the following mathematics. This is in line with Whitman's opinion (Prahmana, 2014) that a professional teacher is able to innovate in the teaching and learning process. The approach needed in learning mathematics is an approach that is able to activate students in constructing their knowledge, so students have an awareness of what they already know and don't know and how they choose the right strategy to solve a problem. one of which can be done through a Geogebra-assisted Metacognitive Guidance approach.

Metacognitive comes from two words namely meta and cognitive means something that exceeds or more than the other while cognitive means knowledge. So metacognitive language is a problem in controlling or playing with existing knowledge to produce new ideas or solve problems. According to Akyüz, Yeti, \& Keser (Komala \& Qintani, 2017), Metacognitive Guidance (MG) is a learning support system used to practice cognitive skills where metacognition skills are an important part of human cognition. Dirkes (Khotimah, 2018) defines metacognition as the ability to identify what is already known (what you know) and what is not yet known (what you don't know), linking new information or knowledge with previously acquired knowledge, planning completion strategies, as well as inviting and evaluating the thought process that is carried out.

According to Pratiwi and Shah (Khotimah, 2018) the learning phase with the metacognitive guidance approach includes the following stages: (1) the conscious process stage, namely through the process of determining learning objectives, determining learning resources, determining good judgment in learning, determining the level of learning motivation and the level of learning student difficulties; (2) the stages of planning learning to determine the scale of learning priorities, organizing learning, and using various learning strategies such as outlining, mind mapping and other learning strategies; (3) monitoring and reflection stages of learning through questions like, asking if this material is useful for me?(Ahmed, 2015)(Herlanti et al., 2017)

Geogebra stands for geometry-Algebra which is one of the mathematical software in terms of geometry and algebra. This software can be used to visualize geometric drawings to make it more clear and accurate so that this software can be used in learning to construct mathematical concepts. This is in line with Mahmudi's opinion (Khotimah, 2018) GeoGebra offers an effective opportunity to create an interactive online learning environment that allows students to explore various mathematical concepts.

The advantages of GeoGebra according to Khotimah (2018) (Sari et al., 2019)in mathematics learning include the following: a) can produce geometric paintings quickly and thoroughly compared to using a pencil, ruler, or term, b) the existence of animation facilities and manipulation movements (dragging) in GeoGebra can provide clearer visual experience for students in understanding the concept of geometry, c) can be used as feedback / evaluation to ensure that the painting has been made right, d) makes it easier for teachers/students to investigate or show the properties that apply to a geometry object. 
Things that need to be considered by teachers other than KBKM are students' initial mathematics ability (KAM). KAM is a skill possessed by students before the mathematics learning process is carried out (Istianah, 2013). KAM which is owned by students also varies from one student to another if viewed from the level of mastery of students it can be distinguished between students who have high, medium and low KAM. KAM students contribute greatly to students' mathematics learning achievement.

KAM students need to pay attention to the teacher before learning because there is a hierarchy in learning mathematics meaning understanding of the material which requires new mastery of the previous material (Usdiyana, et al, 2009: 8). However, the reality is that teachers rarely pay attention to the KAM that is owned by students. As expressed by Sutama (2011: 15) that mathematics learning has not been effective so far, one of the factors is that teachers in teaching tend to pay less attention to KAM. So, a teacher must know the KAM of students to minimize the opportunities of difficulties faced by students in understanding the material to be taught. In addition, by knowing students' initial abilities that vary teachers can choose learning models that are suitable for use in class so that learning that takes place in the class can be effective. Based on this, then in this study, it is suspected that there will be an interaction between KAM and learning towards the improvement of KBKM.

\section{RESEARCH METHOD}

This type of research used in this study is a quasi-experiment which aims to find out the improvement of students' KBKM through Geogebra MCG learning. This research was conducted in one of the State High Schools in Cimahi City in the even semester of the 2018/2019 school year which took place in February-April 2019 for 10 meetings for the experimental and control classes. The study population was all students in one of the high schools in Cimahi City while the sample of this study was class XI students at the school by taking a sample of two classes of 65 people which consisted of 32 students in class XI Natural Science 4 as an experimental class and 33 students in class XI IPA 5 as a control class. The independent variables in this study are Geogebra rock learning and normal learning, while the dependent variable is the ability to think critically mathematically. and control variables, namely students' initial mathematical abilities in groups (high, medium and low).

The research design used in this study was the pre-test-post test control group design. The instrument used to obtain data in this study was an initial mathematical ability test, a mathematical critical thinking ability test. The data in this study consisted of testing for normality, testing for homogeneity, testing for average differences, calculating the gain index, and testing hypotheses. Testing all statistical hypotheses in this study using the Two Path ANOVA formula.

How to determine the level of student ability is done by dividing students into 3 groups based on the math ability test scores given by researchers.

1) High ability: value $\geq 15$

2) Medium ability: $10 \leq$ value $<15$

3) Low ability: value $<10$

\section{RESULTS AND DISCUSSION Results}

The study aims to analyze the achievement and improvement of the ability to think Critically Mathematically who obtain a metacognitive guidance approach 
compared to normal learning seen from KAM and examine whether there is an interaction between CBC and MCG approaches. KAM illustrates knowledge and skills in mathematics before being involved as subjects in research. Data analyzed in the form of quantitative data obtained from the initial value of the initial mathematical ability and the results of tests of mathematical critical thinking. Based on the initial ability score, then students are divided into three levels, namely high, medium, and low. The results of students' initial abilities are categorized as good, sufficient and lacking. For the criteria for determining the level of students can be seen in Table 1 .

Table 1. Grouping Criteria Based on Initial Capabilities

\begin{tabular}{cll}
\hline Description & Interval & Level \\
\hline good & $15-20$ & high \\
enough & $10-14,9$ & medium \\
less & $0-9,9$ & low \\
\hline
\end{tabular}

After testing the prerequisite data analysis it can be found that the N-Gain critical thinking mathematical learning is normally distributed and homogeneous, the analysis used is parametric analysis using two-way ANOVA. The results of the two paths ANOVA summary for testing the first and second hypotheses are presented in Table 2.

Tabel 2. Dependent Variable: KBKM

\begin{tabular}{lrrrrr}
\hline Source & $\begin{array}{c}\text { Type III Sum of } \\
\text { Squares }\end{array}$ & df & \multicolumn{1}{c}{$\begin{array}{c}\text { Mean } \\
\text { Square }\end{array}$} & F & \multicolumn{1}{l}{ Sig. } \\
\hline Corrected & $331.113^{\mathrm{a}}$ & 5 & 66.223 & 27.357 & .000 \\
Model & 6759.657 & 1 & 6759.657 & 2792.506 & .000 \\
Intercept & 38.279 & 1 & 38.279 & 15.813 & .000 \\
CLASS & 290.747 & 2 & 145.374 & 60.056 & .000 \\
LEVEL & 6.259 & 2 & 3.129 & 1.293 & .281 \\
CLASS * LEVEL & 159.762 & 66 & 2.421 & & \\
Error & 9137.000 & 72 & & & \\
Total & 490.875 & 71 & & & \\
Corrected Total & & & & & \\
\hline
\end{tabular}

a. R Squared $=.675$ (Adjusted R Squared $=.650$ )

(Output SPSS)

Based on Table 2, the first statistical hypothesis testing is carried out to test whether the increase in mathematical critical thinking skills of students taught with the metacognitive guidance approach is higher than students taught with ordinary learning. The results obtained show that the F value on learning factors (MCG and PB learning) is 15,813 with a significance value of 0,000 smaller than the significance level of 0.05 , so $\mathrm{H}$ is rejected. In other words, there are differences in the increase in mathematical critical thinking skills between students who are given MCG learning compared to students who are taught PB learning.

The second statistical hypothesis testing is done to test whether there is an interaction between students 'initial mathematical abilities and learning to increase students' mathematical critical thinking skills. The results obtained indicate that at a significant level of $5 \%$ or 0.05 the $F$ value of 1.293 with a significance value of 0.281 is 
greater than the significance level of 0.05 so that $\mathrm{H}$ is accepted. Therefore, it can be concluded that there is no interaction between learning (MCG learning and PB learning) and KAM students (high, medium and low) on increasing students' mathematical critical thinking skills. Graphically, it can be seen in Figure 1 below.

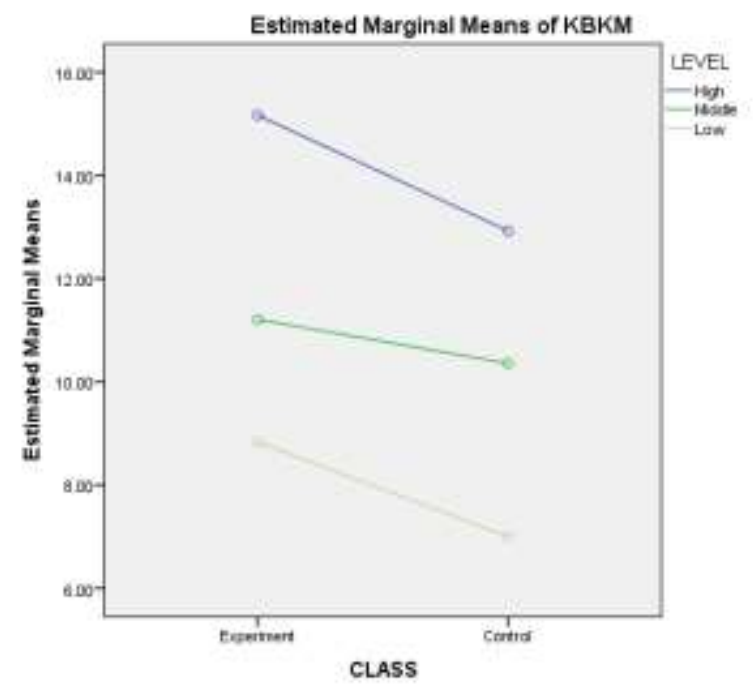

Figure 1. Estimated Marginal Means of KBKM

Figure 1 above shows that the experimental class lines show parallels or do not intersect with the control class lines. From Figure 1 above it can also be seen that the average increase in mathematical critical thinking skills of students who are given MCG learning is for the low KAM category (8.83), the medium KAM category (11.21) and the high KAM category (15.17) while the average increase in students' mathematical critical thinking skills given PB learning are: the low KAM category (7.00), the medium KAM category (10.35) and the high KAM category (12.92). Furthermore, the average difference in mathematical critical thinking skills between students who were given MCG learning and students who were given PB learning in a row for low KAM students was 1.83, moderate KAM was 0.86 and high KAM was 2.25. The difference in the average increase for all KAM categories if tested statistically the difference is not so meaningful that it can be concluded that there is no interaction between learning with KAM to increase students' mathematical critical thinking abilities.

The following will describe some of the factors related in this study, namely learning factors, mathematical critical thinking skills, the interaction between learning used with students' initial mathematical abilities to improve mathematical critical thinking skills.

\section{Discussion}

From the results of the study, it was found that all indicators of mathematical critical thinking ability had increased both in the experimental class and in the control class where the increase in mathematical critical thinking ability of students who were given MCG learning was higher than students who were given PB learning. Although, an increase in students' mathematical critical thinking skills in these two classes if categorized is still in the medium category where it is obtained that the N-gain mathematical critical thinking ability of students in the experimental class who were 
given MCG learning was 0.579 and in students in the control class was 0.3153 . The increase in critical thinking skills obtained in this study is better when compared with the results of research by (Nugraha, 2018) in which an increase in mathematical critical thinking skills of students in the experimental class who were given problembased learning by 0.414 and increased students' mathematical critical thinking skills in the classroom control of 0.215 .

Each student has a different learning experience during the learning process (Prahmana, 2017). One of the most influential factors on the ability to think critically mathematically is learning, especially learning that uses the MCG approach. The stages carried out in MCG, begins with: (1) comprehensive questions, namely the provision of contextual problems by giving a number of questions thoroughly to students to give students the opportunity to understand and solve contextual problems individually or in groups. These problems can be in the form of exercises, the formation or discovery of concepts, procedures or non-routine resolution strategies. If students are not able to relate previous mathematical concepts with the information contained in the problem, the teacher can provide assistance indirectly, namely by giving questions in the form of scaffolding to students, resulting in interactions between students and teachers, students and students, or students with the context of the problem. The teacher's function in learning MCG is as a facilitator and mediator; (2) constructing connections, i.e. build relationships between the problems they face to find solutions to those problems. With the help of GeoGebra students are able to arrange relationships of problems in mathematics; (3) use of strategies, i.e. using appropriate strategies to solve mathematical problems by applying appropriate mathematical concepts in solving mathematical problems; (4) reflecting, namely efforts to explore what has been found in solving problems by discussing the group's work as an invention.

MCG learning in the process of learning there is the principle of reinvention, this shows that mathematics is not given to students as something that is ready, but students must construct or find concepts through the resolution of contextual problems that are realistic for children. The learning process of a real situation then organizes, arranges problems, identifies aspects of the problem mathematically and then through interaction it is expected that students find the mathematical concepts themselves, which can later be applied to different problems and situations. Thus, the process of learning mathematics takes place in the interaction of the social environment. In the reflection in learning will be given a special time in the discussion of problem-solving activities in groups or classically. This is done because at this stage students will interact actively with other students, the teacher, the material and the environment, so that it is expected to be able to foster students' mathematical critical thinking abilities. This activity is carried out for each topic taught in learning in this study. So, the opportunity for students to interact interactively is highly demanded in the learning done. This aims in addition to finding problem-solving by interacting between group members, teachers and the learning environment which will hopefully be able to improve students' mathematical critical thinking skills. Thus, giving contextual problems really determine the reflection activities in MCG learning.

Learning is done by group discussions of five to six people. This is done with the aim of activating students interactively in groups, making it easier for researchers/instructors to provide assistance through the form of questions (scaffolding), and growing student knowledge. From the learning process in one of the high schools in Cimahi City, it seems that they are very happy with group learning, 
they are very interactive, from observations, that they have a feeling of competition between groups, in this case, they want to show that their group is the best. In fact, the process of interaction that occurs at the two schools includes: (1) At the beginning of completion, students have used the initial knowledge of the completion process, students have applied it to an indefinite integral formula. At this stage, students have used certain indeterminate and certain integral concepts. At the end of the settlement, they have found the concept of finding breadth and volume with integrals (reinvention).

The results of data analysis both from descriptive analysis and statistical tests show that increasing students' mathematical critical thinking skills among students whose learning uses approaches or informal knowledge so that they arrive at the completion of determining area and volume with an integral method, in MCG learning, this is called the connection stage, (2) In the middle of the MCG is better than ordinary learning. The increase occurred at high, medium and low KAM levels, this shows that MCG learning can improve mathematical critical thinking skills of High School students. From the results of data analysis, it was found that the learning approach factor had a significant influence on increasing students' mathematical critical thinking abilities. That is, there is an increase in students' mathematical critical thinking skills if students are grouped according to the learning approach. It is possible that the improvement of students' mathematical critical thinking skills is triggered by MCG which in the implementation of learning always pays attention to the principles and characteristics of MCG. Through the principles of MCG, learning is focused on students' ability to reinvent mathematical concepts.

The process of reinventing mathematical concepts is carried out with the help of GeoGebra software. Teaching material developed in accordance with the characteristics of MCG which contains problems of daily life. Then from the beginning, the context is designed as informal mathematics (model of), it is hoped that students can develop students' mathematical critical thinking skills. This is in line with Ennis's opinion that including critical thinking in mathematics is thinking that identifies, generalizes, analyzes and clarifies all aspects that exist in a situation or a problem. It is through learning activities that are designed in accordance with the principles and characteristics of MCG that enable the emergence of mathematical critical thinking indicators. This can be seen when students work on a given problem, then students will carry out activities identifying problems, generalizing, analyzing, clarifying. This all fits the characteristics of mathematical critical thinking.

From some of the findings above, researchers can conclude that there is no interaction between learning with students 'initial mathematical abilities to increase students' mathematical critical thinking. The results of this study are in line with the results of Syahbana's research (2012) that there is no interaction between the learning approach and students 'initial mathematical knowledge (high, medium, low) on increasing students' critical mathematical thinking abilities.

\section{CONCLUSION}

Based on data analysis and deepening of research findings and discussions that have been presented previously, conclusions are obtained:

1. Achievement of Mathematical Critical Thinking abilities Students who use the Metacognitive Guidance approach is better than those who use normal learning at the beginning of high, medium and low mathematical abilities

IJEME, Vol. 3, No. 2, September 2019, 129-138. 
2. Increased Mathematical Critical Thinking Ability Students who use the Metacognitive Guidance approach are better than those who use ordinary learning on high, medium and low mathematical initial abilities

3. There is no interaction between learning with students 'initial mathematical abilities to increase students' mathematical critical thinking abilities

\section{REFERENCES}

Ahmatika, D. (2016). Peningkatan Kemampuan Berpikir kritis siswa dengan pendekatan inquiry/discovery. Jurnal Euclid, vol.3, No.1, p.394.3(1), 394-403.

Ahmed, A. E. H. H. dan E. Y. E. (2015). Impact of Metacognitive Strategies on Academic Achievement Among Special Education Students in Jazan University. International Journal of Education and Research, 3(3), 608.

Aripin, U., Setiawan, W., \& Hendriana, H. (2019). Critical Thinking Profile of Mathematics in Integral Materials. Journal Of Educational Experts (JEE), 2 (2), 97106.

Hendroanto, A., Istiandaru, A., Syakrina, N., Setyawan, F., Prahmana, R. C. I., \& Hidayat, A. S. E. (2018). How Students Solves PISA Tasks: An Overview of Students' Mathematical Literacy. International Journal on Emerging Mathematics Education, 2(2), 129.

Herlanti, Y., Mardiati, Y., Wahyuningtyas, R., Mahardini, E., Iqbal, M., \& Sofyan, A. (2017). Discovering learning strategy to increase metacognitive knowledge on biology learning in secondary school. Jurnal Pendidikan IPA Indonesia, 6(1), 179-186.

Hidayat, W., \& Aripin, U. (2019, February). The improvement of students' mathematical understanding ability influenced by argument-driven inquiry learning. In Journal of Physics: Conference Series (Vol. 1157, No. 3, p. 032085). IOP Publishing.

Istianah, E. (2013). MODEL ELICITING ACTIVITIES ( MEAs ) PADA SISWA. Meningkatkan Kemampuan Berpikir Kritis Dan Kreatif Matematika Dengan Pendekatan Model Eliating Activities (MEAs) Pada Siswa, 2(1), 43-54.

Marlina, E., \& Harahap, E. (2018). Mengembangkan Kemampuan Berpikir Kritis dan Resiliensi Matematik Melalui Pembelajaran Program Linier Berbantuan QM for Windows. Matematika, 17(2), 59-70.

Nugraha, W. S. (2018). Peningkatan Kemampuan Berpikir Kritis Dan Penguasaan Konsep Ipa Siswa Sd Dengan Menggunakan Model Problem Based Learning. EduHumaniora, 10(2), 115-127.

Nuryanti, L., Zubaidah, S., \& Diantoro, M. (2018). Analisis Kemampuan Berpikir Kritis Siswa SMP. Jurnal Pendidikan: Teori, Penelitian, Dan Pengembangan, 3(2), 155-158. https://doi.org/10.17977/jptpp.v3i2.10490. 
Prahmana, R. C. I., \& Suwasti, P. (2014). Local instruction theory on the division in mathematics GASING. Journal on Mathematics Education, 5(1), 17-26.

Prahmana, R. C. I. Team Accelerated Instruction, Initials And Problem-Solves Ability In Junior High School. International Journal on Emerging Mathematics Education

Putri, R.I.I., \& Zulkardi. (2019). Designing jumping task on percent using PMRI and collaborative learning. International Journal on Emerging Mathematics Education, 3(1), 105-116. http://dx.doi.org/10.12928/ijeme.v3i1.12208.

Setiawan W and Sari V T A 2019 The effectiveness of cognitive conflict on the concept of differential J. Phys. Conf. Ser. 1157

Sari, P. C., Eriani, N. D., Audina, T., \& Setiawan, W. (2019). Pengaruh pembelajaran berbantuan geogebra terhadap peningkatan kemampuan pemecahan masalah matematik siswa smp. 01(03), 411-416.

Senjayawati, E. (2018). Peningkatan Kemampuan Berpikir Kritis Matematik Siswa Smk Melalui Pendekatan Problem Posing. JURNAL E-DuMath, 4(1), 58. https://doi.org/10.26638/je.588.2064. 